early Italian paintings, and he is often remembered in the art world for his gifts of these paintings to his old college and especially to the Ashmolean Museum at Oxford. With Sir Thomas Lawrence he has been held chiefly responsible for the evolution of the Ashmolean from 'Tradescant's 'closet' of antiquarian and biological 'rarities' to the unique museum of art that it is to-day.

Similarly, in the course of his service at the Embassy in Vienna, Strangways introduced to England the Austrian pine, Pinus austriaca, and in his later years he devoted much of his time to horticultural matters in the gardens of his family home at Abbotsbury in Dorset.

The height of his diplomatic career came on August 15,1835 , when he was appointed Under-Secretary of State for Foreign Affairs, which post he held for five years under the dominating leadership of Palmerston as Foreign Secretary.

Nevertheless, in spite of his diplomatic duties and other interests, he retained his geological inclinations throughout. In 1820 he became vice-president of the Geological Society of London (four years before his old teacher Buckland became president for the first time) and he regularly attended its meetings.

It is interesting to note from the files at the Society that it was then the custom of the diplomatic service to pass on geological as well as political information to London. A letter from Strangways to the Society in 1837, for example, enclosed a report from the British Consul at Beirut about a recent earthquake in that area.

After his retirement from the diplomatic service in 1849, he concentrated on his many scientific and charitable interests. He helped to found the Dorset County Museum in Dorchester, and presented it with some of his geological specimens. $\mathrm{He}$ also gave many books and specimens to the Geological Society. He did not marry until he was sixty-two (in 1857) and succeeded to the earldom the following year, on the death of his half-brother. He was succeeded in his turn by his nephew. It is reasonable to suppose that he may have been responsible for arousing an interest in geology in his young kinsman Charles Edward Fox Strangways (1844-1910). The latter was a leading officer of the Geological Survey for many years and is especially remembered for his series of large memoirs on the Jurassic rocks of Britain.

W. T. H. Fox Strangways is well known to Russian geologists as one of the founders of the science in their country. On this, the centenary of his death, it is appropriate that he should also be remembered in Britain.

We thank Dr. R. F. Gekker of the Palaeontological Institute in Moscow, whose original enquiry led to this article, and Mr. J. M. Edmonds of Oxford for information about Strangways's studies there.

1. Strata des environs de St. Pétersbourg en ordre de position gélogique. St.
Petersburg (one page, un-numbered) (1819).
2 "Description of the Rapids of Imatra, on the Voxa River, in Carelia; with
an Outline of the Probable History of their Formation; and a Notice
of the Bursting of the Lake Souvando into the Ladoga in the Year 1818".
Trans. Geol. Soc. Lond., 5,340 (1821).
3 "Description of Strata in the Brook Pulcovea Near the Village of Great
Pulcovea in the Neighbourhood of St. Petersburg". Trans. Geol. Soc.
Lond., $5,382(1821)$.
" "Geological Sketch of the Environs of Petersburg". Trans. Geol. Soc.
Lond., 5, 392 (1821).
" An Outline of the Geology of Russia". Trans. Geol. Soc. Lond., Ser. 2,1 (1822).

\title{
OBITUARIES
}

\section{Prof. E. W. H. Cruickshank}

Ernest Willtam Henderson Cruxckshank, emeritus professor of physiology in the University of Aberdeen, died in Aberdeen on December 29, 1964.

He was born in Edinburgh in 1888, received his early education at Robert Gordon's College, Aberdeen, and studied medicine in the University of Aberdeen, where he graduated M.B., Ch.B. in 1910. Very early in his career, his enquiring mind made him turn to research, and in 1912, having been awarded a Carnegie Research fellowship, he went to work under E. H. Starling at the Physiology Department of University College, London. At that time Starling was engaged in his classical studies on the heart-lung preparation. In his first paper, published from University College, Cruickshank made the quite unexpected observation that the glycogen content of the heart of the diabetic dog was higher than that found in the non-diabetic animal. He also compared the glucose consumption of the normal and the diabetic heart. His experience at University College influenced his future interests decisively; throughout his career he remained interested in problems of cardiac metabolism.

His work at University College was cut short by the First World War, during which he succeeded in joining the Royal Army Medical Corps after having been rejected at first because of the loss of an eye when he was a medical student.

After the War came a long and welcome period of peregrinations. In 1919 he went to work with J. Erlanger in the Physiology Department of Washington University Medical School in St. Louis, where he became acquainted with biophysical methods. From there he went as professor of physiology to Peking Union Medical College, which at that time was supported by the Rockefeller Foundation. The four years he spent there he found very interesting, and in spite of the great demands made on his time by teaching and administrative duties, he published a number of papers on experimental tetany.

The next two years were spent at the Physiological Laboratory in Cambridge and University College, London, as a Travelling Research Fellow of the Rockefeller Foundation. In Cambridge he came under the influence of Joseph Barcroft and published papers on problems of renal haemodynamics and the spleen as a reserve organ for haemoglobin. Prof. Cruickshank often talked with great pleasure of this time and was very proud when, years later, Sir Joseph Barcroft came to Aberdeen to acquire from his former pupil the technique of the heart-lung preparation in the rat. An interesting paper on the coronary circulation was the result of work done with G. V. Anrep at University College.

In 1926 Cruickshank went to the Prince of Wales Medical College in Patna as professor of physiology and biochemistry. Three years later he was appointed professor of physiology at Dalhousie University in Halifax. During the next six years he resumed work on the problems in which he had first become interested in Starling's laboratory and developed a reliable technique for investigating the metabolism of cardiac muscle in the heart-lung preparation of the dog. He always considered this work, which was later continued in Aberdeen, as his most important contribution to physiology. The results showed that, while cardiac muscle normally uses carbohydrate as a source of energy, in the absence of carbohydrate fatty acids form an available supply of energy. He also showed that in the diabetic heart insulin restores the ability of the muscle to utilize glucose.

When he was appointed to the Regius chair of physiology in Aberdeen in 1935, he continued with the line of research initiated at Dalhousie. However, in order to improve the experimental design he decided to develop the heart-lung 
proparation in the rat, a species with much smaller individual variations than the dog, hitherto used by workers in this field. A great deal of preparatory work had to bo done concerning both surgical technique and apparatus; in this he was ably supported by his technician, A. M. Taylor, who served him as skilfully as he had dono his two predecessors, J. A. McWilliam and J. J. R. Macleod.

Quite soon aftor his arrival in Aberdeen, Prof. Cruick shank, through his close association with the Rowett Research Institute, becamo interested in problems of nutrition and, whon asked as a newly appointed professor to give the Farquhar Thomson Lectures, he chose nutrition as his subject. In a modified form these lectures woro published two years later in book form, undor the title Food and Physical Fitness. This book was in great demand and was republished in an enlarged form as $\boldsymbol{F}^{\prime}$ ood and Nutrition in 1946 and in a revised edition in 1951.

At the beginning of the Second World War he was uppointed to the Nutrition Sub-committee of the Scientifio Advisory Committoo of the Department of Health for Scotland and served as its chairman during 1944-48.

Prof. Cruickshank was a quiet and gentle man who showed great courage and perseverance in adversity. This quality stood him in good stoad when, after a cerebral vascular illness in 1947, he was prevented from continuing with the exporimental work which meant so much to him. Because of his experience in the universities of many different countries, ho was asked several times during tho ninoteen-fifties by the World Health Organization to act as consultant and visit modical schools in various parts of the world. It was characteristic of him that about a year ago he accepted an invitation to visit the U.S.S.R. to discuss problems of medical education.

H. W. KosterLitz

\section{Dr. José Ramirez de Arellano}

Dr. José Ramírez de Arfiliano was killod in a car accident in Moxico City on September 9, 1964.

Dr. Ramírez obtained the doctor of medicine dogrce in the University of Mexico, working during this time in the laboratory of Prof. Arturo Rosenblueth. In 1956 he wont to the United States, where, following an interval with Prof. Guzman Barron at the University of Chicago, he joined the staff of the Johnson Research Foundation of the Univorsity of Pennsylvania. On roturning to Mexico City in 1958, he spent sovoral years at the Instituto Nacional de Cardiologia before joining the Department of Biochemistry in the newly established Centro do Invostigacion y de Estudios Avanzados del Instituto Politecnico Necional.

Dr. Ramírez had a deep interost in all phases of biology, but particularly in bioonergetics, and made unique cons. tributions to the investigation of such difforont systoms as mammalian muscle and photosynthotic bacteria. As an examplo, his work on responses of cytochromes to single contractions of cardiac muscle can be regarded as classic, and led him on to oxamino furthor the possibility of a phosphorylation site in the cytochrome oxidase. His work on the changes in absorption spectra of eytochromes and carotenoids of photosynthotic bacteria following illumination or oxygenation, and the response of cyto. chromos to adenosine diphosphates in $R$. rubrum chromatophores stands out as another landmark of progregs in the investigation of cnergy conservation reactions.

José Ramírez will be remembered by his many friends as a dedicated sciontist who did ovorything in his powor to make the experiment a success, out of the warmth of his heart and his abiding interest in tho progross of science. Ho had on outstanding talent for handling both complicatod biological preparations and sophisticated apparatus. With his perceptivo mind and rapid grasp of complex biological problems, he was a thoughtful col- league from whom much could be learned. He will also be romembered for his honesty, his warm and charming personality, his delightful sense of humour and his contagious enthusiasm. Those of us who know him feel that we were fortunate to have been his colleague and his friend.

LUCILE SMITH

Britton Chance

\section{Mr. P. F. Holmes, O.B.E.}

Paul Foster Holmes was born at Hornsoa, in the East Riding of Yorkshire, in November 1913. He was at school at Charterhouse from where he won an Exhibition to Trinity Hall, Cambridge. There he read natural science, played bridgo badly, golf well and worked hard, being awarded a II.i in the Part 2 Zoology Tripos. He stayed on at Cambridgo for two years as a research assistant, taking the opportunities to go on expeditions to Lake Titicaca and Yugoslavia. In 1937 ho joined the biology staff at Shrewsbury School. He served during the Socond World War with the Shropshire Light Infentry, playing a part in reviving the Univorsity at Bologna in 1944-45.

After demobilization he returned to Shrewsbury until August 1, 1947, when he moved across to be the first warden of the Malham Tarn Fiold Centro, one of the first four centres to be established by the Council for the Promotion of Field Studies, as it was then.

His work at Malham was at full flow when he died suddenly in a car crash on December 10, 1964. He was a past-president of the Yorkshire Naturalists' Union, sometime member of the committees of tho British Orni. thologists' Union, the Froshwater Biological Association and the British Ecological Society. At the time ho diod he was a member of the England Committce of the Nature Consorvancy and one of the Minister's nominees on the Wost Riding Park Planning Committee.

He leaves a widow and four daughters.

Paul Holmos was above all else a countryman. $\mathrm{H}_{\theta}$ cared intensely that the beauty, the quiet and the community of the countryside should bo conserved for its own sake and so that urban man, provided he behaver himsolf, should still have hills, coasts, forests and moors unspoilt for his recreation. In later yoars Holmos gave more and more time and thought to the problems of large-scale conservation, and by associating himsolf with constructive planning his knowledge of the countryside in all its ways was quickly gaining him a reputation for undorstanding many points of view and for elfective persuasion against those he boliovod to bo misguided. 'The O.T3.E. he received in the 1964 New Year's Honour's marked his contributions.

Holmes was a naturalist in the old-fashioned nse of tho word. Nothing that affected the landscape-and the Pennine Craven landscape in particular-was left aside. Plants and animals, the rocks and their history, the activities of man, tho wind and tho rain-he was so much at homo in the environment in which he delighted to live that $I$ doubt if $h_{1}$ roalized how unusual, and valuable, was his knowledge of it.

He wrote little but well. Had he been given time--and had he been prodded-ho would have come to writo more. As it was, ho was constantly busy for the benofit of other people and his services were in ever-greater demand.

No man owed Paul Holmes a grudgo; no man saw him lose his tempor; no man was ever set at a misleading disadvantage by anything that Paul Holmes might have said. He was himself a quiet character, dotormined to the point of obstinacy, humorously good-natured and very pationt, as befits a fisherman; devoted to his splendic family, knowing himsolf to bo fortunato in his life, he wishod so much that others might share his pleasures. So fow others achieved his standards that the gap he leaves is all too obvious. Paul Holmes will bo dooply mourned by all kinds of peoplo who will never forget him.

JOHN BARRITT 